\title{
EFFECT OF EATING HABITS, BMI VALUE, PHYSICAL ACTIVITY AND SMOKING CIGARETTES ON BLOOD LIPID INDICES OF ADOLESCENT BOYS FROM POLAND
}

\author{
Ewa Piotrowskal ${ }^{l}$, Michaela Godyla-Jabłońskil, Monika Bronkowska ${ }^{l}$
}

${ }^{1}$ Faculty of Biotechnology and Food Science, Wrocław University of Environmental and Life Sciences, Chełmońskiego street 37, 51-630 Wrocław, Poland

\begin{abstract}
Background. The lifestyle of young boys has impact on the risks of cardiovascular diseases.

Objective. The aim of the study was to evaluate the effect of atherosclerosis risk factors determined by overweight and obesity and lifestyle, i.e.: eating habits, low physical activity and smoking cigarettes, on blood lipid profile of boys at the age of 16 to 18 .

Material and Methods. The study covered 369 boys from secondary schools. They were evaluated for the supply of dietary constituents with atherogenic and protective actions, for nutritional status acc. to Cole's criteria, the level of physical activity, and smoking cigarettes. Lipid metabolism was determined based on criteria recommended by the American National Cholesterol Education Program (NCEP). Logistic regression analysis was conducted and risk odds ratio [OR] was determined.

Results. Analyses showed the boys to be characterized by overweight (10.8\%) and obesity (2.7\%), and by inappropriate concentration of total cholesterol (26.5\%), LDL (13.3\%), HDL (21.7\%) and triglycerides (41.7\%). High BMI turned out to be a significant risk factor of an elevated total cholesterol concentration: $[\mathrm{aOR}]=2.27$; triglycerides: $[\mathrm{aOR}]=2.35$ and LDL: $[\mathrm{aOR}]=2.41$. Low physical activity was found to negatively affect the concentration of LDL: $[\mathrm{aOR}]=1.88$. The boys smoking cigarettes were shown to have a reduced HDL: $[\mathrm{aOR}]=1.65$. The total content of fat and saturated fatty acids in diet exerted a significantly negative impact on blood lipid profile of the boys.

Conclusions. The lifestyle of the young boys was demonstrated to determine the risk of cardiovascular diseases. Overweight and obesity, abdominal obesity in particular, were found to be a significant risk factor of disorders in their lipid metabolism.
\end{abstract}

Key words: boys, eating habits, BMI, risk factors, blood lipid indices

\section{STRESZCZENIE}

Wprowadzenie. Styl życia młodych chłopców ma wpływ na ryzyko chorób sercowo-naczyniowych.

Cel. Celem pracy była ocena wpływu czynników ryzyka miażdżycy zależnych od nadwagi i otyłości oraz stylu życia, tj.: nawyków żywieniowych, niskiej aktywności fizycznej i palenia papierosów, na profil lipidowy krwi u chłopców w wieku od 16 do 18 lat.

Materiał i metody. Badaniem objęto 369 chłopców ze szkół średnich. Zostali oni ocenieni pod kątem podaży składników diety o działaniu aterogennym i ochronnym, pod kątem stanu odżywienia według kryteriów Cole'a, poziomu aktywności fizycznej i palenia papierosów. Metabolizm lipidów określono na podstawie kryteriów zalecanych przez kryteria zalecane przez National Cholesterol Education Program (NCEP). Przeprowadzono analizę regresji logistycznej i określono iloraz ryzyka [OR].

Wyniki. Analizy wykazały, że chłopcy charakteryzują się nadwagą (10,8\%) i otyłością (2,7\%) oraz niewłaściwym stężeniem cholesterolu całkowitego (26,5\%), LDL (13,3\%), HDL (21,7\%) i triglicerydów (41,7\%)). Wysokie BMI okazało się istotnym czynnikiem ryzyka podwyższonego stężenia cholesterolu całkowitego: $[\mathrm{aOR}]=2,27$; triglicerydów: [aOR] $=$ 2,35 i LDL: $[\mathrm{aOR}]=2,41$. Stwierdzono, że niska aktywność fizyczna negatywnie wpływa na stężenie LDL: [aOR] = 1,88. Wykazano, że chłopcy palący papierosy mają obniżoną HDL: [aOR] = 1,65. Całkowita zawartość tłuszczu i nasyconych kwasów tłuszczowych w diecie wywarła znacząco negatywny wpływ na profil lipidowy krwi chłopców.

Wnioski. Wykazano, że styl życia młodych chłopców determinuje ryzyko chorób sercowo-naczyniowych. Stwierdzono, że nadwaga i otyłość, w szczególności otyłość brzuszna, stanowią istotny czynnik ryzyka zaburzeń metabolizmu lipidów.

Słowa kluczowe: chłopcy, nawyki żywieniowe, BMI, czynniki ryzyka, wskaźniki lipidów we krwi

Corresponding author: Michaela Godyla-Jabłoński, Faculty of Biotechnology and Food Science, Wrocław University of Environmental and Life Sciences, Chełmońskiego street 37, 51-630 Wrocław, Poland, phone: +48 884734 030, e-mail: michaela.godyla@upwr.edu.pl 


\section{INTRODUCTION}

The atherosclerotic process begins already in the childhood or in the early adolescence and is proceeding with age $[10,16]$. Results of pathophysiological and epidemiological investigations show explicitly that early dysfunctions of arterial vessels endothelium and arterial hypertension commence much earlier $[6,35]$. A number of cross-sectional cohort studies $[7,45]$, have enabled determining risk factors of atherosclerosis in the adolescents. Results of multiple earlier investigations conducted in the XXth and XXIst century, among others: research by Lutsey et al. [26], $L i$ et al. cross-sectional studies [23], research by Kouki et al. [22], and that by $H u$ et al. [17,18], have pointed to dependencies between lifestyle and anthropometric and biochemical indices as well as development of cardiovascular diseases (CVD). The composition of food products affects lipid metabolism of a body to a various extent, it may both enhance and inhibit atherogenic processes $[39,46]$. The healthpromoting effect of fruits and vegetables has also been thoroughly documented [14, 34, 36].

The objective of the study was to evaluate the effect of atherosclerosis risk factors determined by lifestyle, i.e.: eating habits, overweight and obesity, low physical activity and smoking cigarettes, on blood lipid profile of boys at the age of 16 to 18 years from the area of Poland.

\section{MATERIAL AND METHODS}

The study was conducted from 2008 to 2018 in a randomly selected group of 369 boys at the age of 16-18 years attending secondary schools in Poland (the city of Wrocław). Numbers of boys in particular age groups were as follows: 103 boys at the age of 16 (27.9\% of total group), 104 boys at the age of 17 (28.2\%), and 162 boys at the age of 18 (43.9\%).

\section{Ethical aspects}

Parents, guardians or students who were of age, provided written informed consent to the study. In a statement provided guarantees covering confidentiality. The study was approved by the Research Ethics Committee of the Medical University in Wrocław, which is affiliated with the Council for National Research Ethics in Poland.

\section{Nutritional survey}

Eating habits of the boys were evaluated by means of a triple direct nutritional interview conducted 24 hours before examination. The nutritional value of daily food rations of the boys was determined with the use of "Dietetyk" software [33]. Results of eating habits assessments were compared with dietary allowances and recommendations [3, 20, 47].

\section{Nutritional status}

Values of Body Mass Index - BMI (body mass/ body height ${ }^{2}$ ) were computed based on measurements of body mass $[\mathrm{kg}]$ and body height $[\mathrm{m}]$ of the boys. Distributional cutoff values, such as the $85^{\text {th }}$ or $95^{\text {th }}$ percentiles of reference data, have been used most often. More recently, gender- and age- specific cutoff values that are tied to the adult overweight $\left(25 \mathrm{~kg} / \mathrm{m}^{2}\right)$ and obesity $\left(30 \mathrm{~kg} / \mathrm{m}^{2}\right)$ thresholds were developed. In these studies the BMI values obtained were evaluated using standards elaborated by Cole et al. [5].

The BMI values indicating overweight and obesity of the boys reached, respectively: 23.90 and $28.88 \mathrm{mg} /$ $\mathrm{kg}^{2}$ - for the 16-year-olds; 24.46 and $29.41 \mathrm{mg} / \mathrm{kg}^{2}$ - for the 17 -year-olds; and 25.00 and $30.00 \mathrm{mg} / \mathrm{kg}^{2}$ - for the 18 -year-olds. The evaluation of waist circumference values was conducted according to criteria postulated by Katzmarzyk et al. [21]. Threshold values above which an increase is observed in the risk of the incidence of metabolic disorders and arterial hypertension reached: $79.0 \mathrm{~cm}$ - for the boys at the age of $16,79.8 \mathrm{~cm}$ - for those at the age of 17 and $80.4 \mathrm{~cm}$ for those at the age of 18 .

\section{Blood lipid profile}

Blood biochemical indices determined in the study were evaluated based on guidelines of a Group of Experts of the American National Cholesterol Education Program (NCEP) [35]. The criteria of lipid metabolism assessment were as follows: concentration of total cholesterol - threshold 170-199 mg/dl, high $\geq$ $200 \mathrm{mg} / \mathrm{dl}$; concentration of triglycerides - threshold $90-129 \mathrm{mg} / \mathrm{dl}$, high $\geq 130 \mathrm{mg} / \mathrm{dl}$; concentration of LDL-cholesterol - threshold 110-129 mg/dl, high $\geq$ $130 \mathrm{mg} / \mathrm{dl}$; and concentration of HDL-cholesterol threshold 45-35 mg/dl, low $<35 \mathrm{mg} / \mathrm{dl}$.

\section{Risk factors}

Nutritional risk factors adopted in the study included:

- high energy value of diet $>110 \%$ of EAR (Estimated Average Requirement) ( $>3740 \mathrm{kcal})$

- excessive intake of total fats $>30 \%$ of due energy

- excessive intake of SFA (Saturated Fatty Acids) $\geq 10 \%$ of due energy

- excessive intake of cholesterol $>300 \mathrm{mg}$

- high contribution of energy derived from monosaccharides (saccharose) $\geq 10 \%$ of due energy

- low intake of PUFA (Polyunsaturated Fatty Acids) $<6 \%$ of due energy

- low intake of dietary fiber $<20 \mathrm{~g}$

- small consumption of fruits and vegetables $<400 \mathrm{~g}$ 
- overweight and obesity acc. to threshold values by Cole's [5]

- high values of waist circumference acc. to Katzmarzyk et al. [21]

- smoking cigarettes - irrespective of the number and frequency

- lack or low physical activity - exemption from classes of physical education and exercising only during school classes.

\section{Statistical analysis}

Results obtained were subjected to a statistical analysis with the use Statistica 10.0 software by StatSoft Inc. USA. Analysis of logistic regression was conducted and risk Odds ratio (OR) was determined. The level of statistical significance was stipulated at $\mathrm{p}<0.05$.

\section{RESULTS}

Table 1 presents data on selected elements of the nutritive value of an average food ration and mean indices of the nutritional status of the 16-18-year-old boys surveyed in the study $(n=369)$. Figure 1 depicts the percentage of boys with nutritional risk factors and Figure 2 - those with incorrect blood lipid profile, high values of waist circumference as well as overweight and obesity. The energy value of an average food ration reached $3631.2 \pm 1171 \mathrm{kcal}$, which constituted $107.0 \%$ of the (EAR). Considerable individual differences were observed in energy intake, which was indicated by minimal and maximal energy values accounting for 972.1 and $7161.4 \mathrm{kcal}$, respectively. In $43.1 \%$ of the food rations, the EAR for energy intake was exceeded (Table 1, Figure 1).
The content of total fat in the food rations examined turned out to be high. The contribution of fat-derived energy in the total energy value of an average daily food ration reached $36.4 \pm 5.8 \%$. The recommended level of $30 \%$ of energy derived from fats was exceeded in as many as $85.1 \%$ of the food rations. Inappropriate values were also recorded in the structure of fatty acids intake. Especially alarming appeared to a high contribution of SFA $-14.4 \pm 3.4 \%$ of energy in respect of the recommended level of $<10 \%$. A high content of SFA was demonstrated in $90.2 \%$ of the food rations. In contrast, analyses showed a low contribution of energy derived from PUFA in an average food ration, i.e. $5.1 \%$ of energy, with extreme values reaching $2.0 \%$ and $16.1 \%$. Deficiency of PUFA was observed in $75.3 \%$ of the food rations. In the food rations analyzed, the mean content of cholesterol $(554.5 \mathrm{mg})$ exceeded the recommended dietary allowances to a considerable extent (184.8\%). The intake of that component with diet was highly diversified and ranged from 51.6 to $1394.2 \mathrm{mg}$. Its excessive content ( $>300 \mathrm{mg} /$ day) was demonstrated in $84.3 \%$ of the food rations. Dietary fiber content of an average food ration reached $28.9 \pm 10.6 \mathrm{~g}$. It was consistent with the adopted recommended values of $20-40 \mathrm{~g}$, yet the minimal content of this component in the food ration accounted for as little as $9 \mathrm{~g}$, whereas the maximal one - for ca. $69 \mathrm{~g}$. A low content of dietary fiber $(<20 \mathrm{~g} /$ day $)$ was demonstrated in $19.2 \%$ of the food rations. Mean intake of monosaccharides, determined based on the content of saccharose, reached $11.4 \pm 5.1 \mathrm{~g}$, and their excessive concentrations were observed in $59.6 \%$ of the food rations. The content of fruits and vegetables in an average food ration of the boys examined reached $653.7 \mathrm{~g}$, which appeared to be correct in respect of

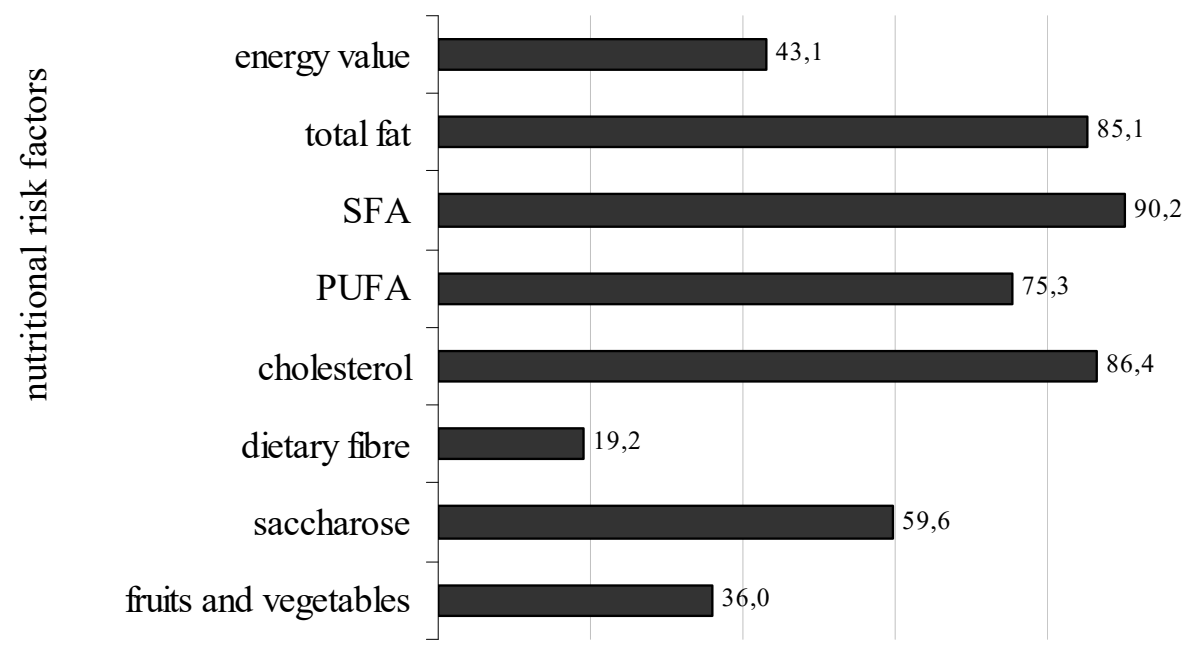

$\%$ of group

Figure 1. Nutritional risk factors in the boys examined $(n=369)$ 
Table 1. Selected components of an average daily food ration and mean indices of the nutritional status of the 16-18-yearold boys examined $(n=369)$

\begin{tabular}{|c|c|c|c|c|c|c|c|}
\hline Dietary components & \multirow[b]{2}{*}{ Unit } & \multirow{2}{*}{$\begin{array}{c}\text { Dietary } \\
\text { allowances and } \\
\text { recommendations }\end{array}$} & \multirow[b]{2}{*}{ Mean } & \multirow[b]{2}{*}{$\mathrm{SD}$} & \multirow[b]{2}{*}{ Min. } & \multirow[b]{2}{*}{ Max. } & \multirow{2}{*}{$\begin{array}{c}\% \text { of dietary } \\
\text { allowances and } \\
\text { recommendations }\end{array}$} \\
\hline Diet assessment & & & & & & & \\
\hline energy value & $\begin{array}{c}\text { kcal } \\
\text { MJ }\end{array}$ & $\begin{array}{c}3400 \\
14.2\end{array}$ & $\begin{array}{c}3631.2 \\
15.2\end{array}$ & $\begin{array}{c}1171.0 \\
4.9\end{array}$ & $\begin{array}{c}972.1 \\
4.1\end{array}$ & $\begin{array}{c}7161.4 \\
30.0\end{array}$ & 107.0 \\
\hline total fat & $\%$ of energy & $<30$ & 36.4 & 5.8 & 19.1 & 65.2 & 121.3 \\
\hline saturated fatty acids & $\%$ of energy & $<10$ & 14.4 & 3.4 & 3.9 & 29.3 & 144.0 \\
\hline polyunsaturated fatty acids & $\%$ of energy & $6-10$ & 5.1 & 1.8 & 2.0 & 16.1 & 85.0 \\
\hline saccharose & $\%$ of energy & $<10$ & 11.4 & 5.1 & 1.3 & 33.9 & 114.0 \\
\hline dietary fibre & $\mathrm{g}$ & $20-40$ & 28.9 & 10.6 & 9.0 & 68.6 & 96.3 \\
\hline cholesterol & $\mathrm{mg}$ & $\leq 300$ & 554.5 & 253.1 & 51.6 & 1394.2 & 184.8 \\
\hline fruits and vegetables & $\mathrm{g}$ & $>400$ & 659.3 & 535.2 & 0.0 & 3342.4 & 164.7 \\
\hline \multicolumn{8}{|l|}{ Nutritional status } \\
\hline body height & $\mathrm{m}$ & & 1.8 & 0.1 & 1.6 & 2.0 & \\
\hline body mass & $\mathrm{kg}$ & & 69.3 & 11.2 & 41.0 & 111.0 & \\
\hline BMI & $\mathrm{kg} / \mathrm{m}^{2}$ & Acc. to Cole & 21.6 & 3.0 & 15.8 & 34.8 & \\
\hline waist circumference & $\mathrm{cm}$ & Acc. Katzmarzyk & 79.8 & 8.2 & 64.0 & 119.0 & \\
\hline cholesterol & $\mathrm{mg} / \mathrm{dl}$ & $<170$ & 156.8 & 93.0 & 269.0 & 26.9 & \\
\hline HDL-cholesterol & $\mathrm{mg} / \mathrm{dl}$ & $\geq 45$ & 52.4 & 15.0 & 106.0 & 10.9 & \\
\hline LDL-cholesterol & $\mathrm{mg} / \mathrm{dl}$ & $<110$ & 86.8 & 40.0 & 400.0 & 28.1 & \\
\hline triglycerides & $\mathrm{mg} / \mathrm{dl}$ & $<90$ & 92.9 & 14.0 & 417.0 & 52.1 & \\
\hline
\end{tabular}

WHO recommendations ( $\geq 400 \mathrm{~g} /$ day). Still, analyses showed great differences in their intake that ranged from $0.0 \mathrm{~g}$ to $3342.4 \mathrm{~g}$. In $36 \%$ of the food rations, quantities of fruits and vegetables were found to be low $(<400 \mathrm{~g} /$ day $)$.

In the examined group of boys, mean body mass accounted for $69.3 \pm 11.2 \mathrm{~kg}$ and mean body height for $1.80 \pm 0.1 \mathrm{~m}$. The mean value of BMI was at a level of $21.6 \pm 3 \mathrm{~kg} / \mathrm{m}^{2}$. Overweight was demonstrated in $10.8 \%$, and obesity in $2.7 \%$ of the boys surveyed. The mean value of waist circumference reached $79.8 \pm 8.2$ $\mathrm{cm}$, and high values of that parameter were observed in $42.3 \%$ of the surveyed (Table 1, Figure 2).

The mean concentration of cholesterol in blood plasma of the 16-18-year-old boys was at a level of $156.8 \pm 26.9 \mathrm{mg} / \mathrm{dl}$; with the minimum value of 93.0 $\mathrm{mg} / \mathrm{dl}$ and the maximum value of $269.0 \mathrm{mg} / \mathrm{dl}$. The threshold concentration of cholesterol, which acc. to current health criteria already requires correction by applying a diet and physical activity, was demonstrated in $18.4 \%$ of the boys, whereas a high concentration of cholesterol - in $8 \%$ of the surveyed.

The mean concentration of the "atherogenic" LDL fraction of cholesterol reached $86.8 \pm 28.1 \mathrm{mg} / \mathrm{dl}$. In some of the boys, the concentration of that cholesterol fraction exceeded the values recommended for adolescents at this age The threshold concentration of LDL-cholesterol was demonstrated in $8.7 \%$ and its high concentration - in $4.6 \%$ of the group examined. The mean concentration of the HDL-cholesterol reached $52.4 \pm 10.9 \mathrm{mg} / \mathrm{dl}$, with the extreme values being 15.0 and $106.0 \mathrm{mg} / \mathrm{dl}$. The threshold concentration of HDLcholesterol was observed in ca. $24.0 \%$ and its low concentration - in ca. $2 \%$ of the group surveyed. The average concentration of triglycerides in blood plasma of the boys examined was $92.9 \pm 52.1 \mathrm{mg} / \mathrm{dl}$; and the extreme value was highly divergent $(14-417 \mathrm{mg} / \mathrm{dl})$. A considerable percentage of the boys $(23.8 \%$ of the group) were characterized by an elevated concentration of triglycerides that ranged from 90 to $129 \mathrm{mg} / \mathrm{dl}$. In turn, their high concentration was shown in $17.9 \%$ of the group surveyed. The habit of smoking cigarettes, irrespective of the number of smoked cigarettes, was observed in $28.4 \%$ of the group examined. A lack or low physical activity, undertaken only at school classes (3 times x $45 \mathrm{~min} /$ week) was demonstrated in $17.3 \%$ of the boys (Figure 2).

\section{Risk factors}

Analyses were also conducted for the effect of selected factors attributable to diet, low physical activity, smoking cigarettes, and high BMI values (overweight acc. to Cole et al. [5]) on blood lipid profile of the boys examined. In addition, the likelihood of blood lipid disorders was estimated by determining the Odds ratio. To this end, an analysis of logistic regression was conducted, the results of which were presented in Table 2. 


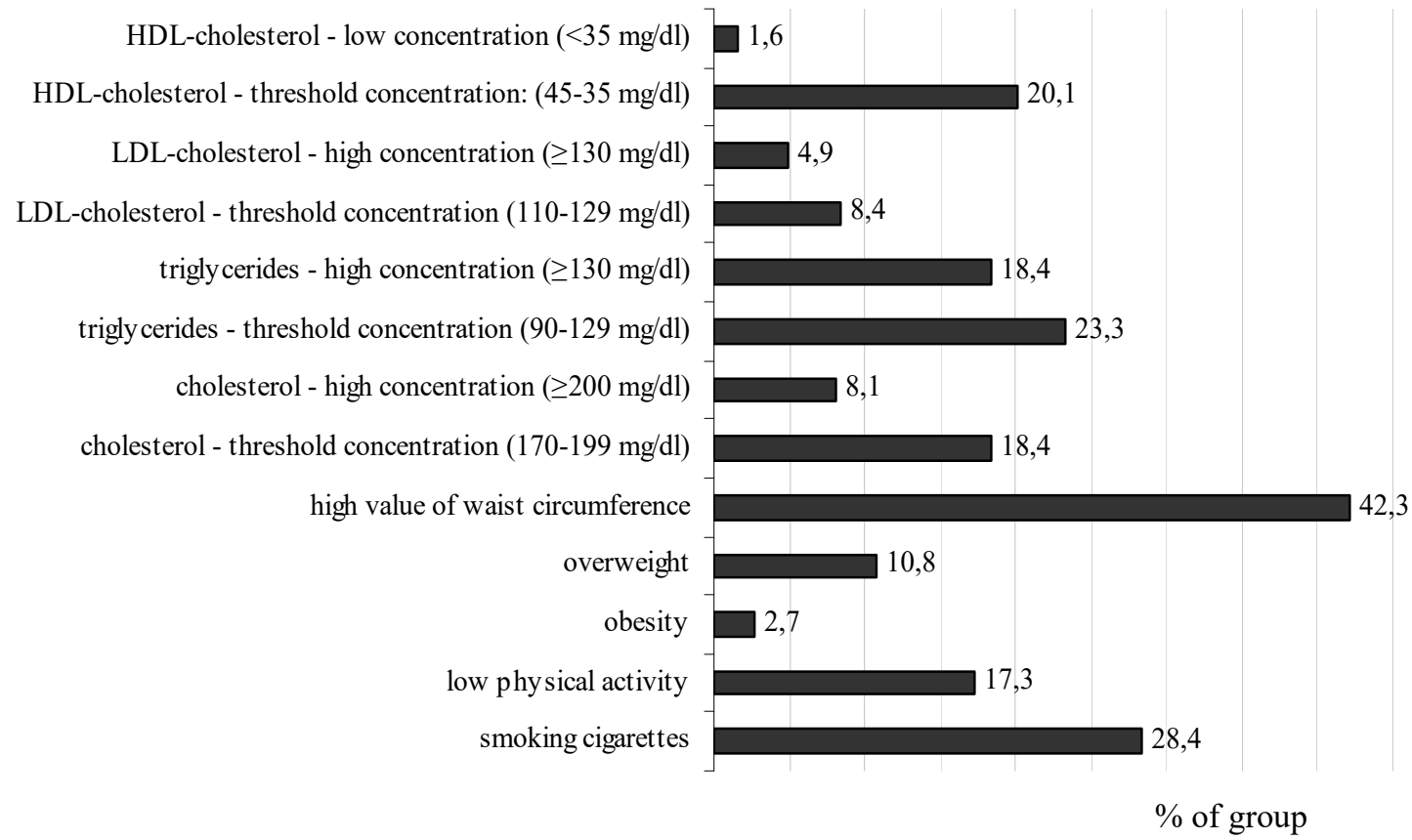

Figure 2. Percentage of boys with incorrect blood lipid indices, high value of waist circumference, overweight and obesity as well as with low physical activity and smoking cigarettes $(n=369)$

Table 2. Effect of selected factors of lifestyle on an increase in the likelihood of the risk of a high concentration of cholesterol, triglycerides, LDL- and HDL-cholesterol in blood of the 16-18-year-old boys examined ( $\mathrm{n}=369)$

\begin{tabular}{|c|c|c|c|c|c|c|c|c|}
\hline Risk factors & \multicolumn{2}{|l|}{ Cholesterol } & \multicolumn{2}{|c|}{ Triglycerides } & \multicolumn{2}{|c|}{ LDL-Cholesterol } & \multicolumn{2}{|c|}{ HDL-Cholesterol } \\
\hline energy & $0.88^{\mathrm{a}}(0.55-1.41)$ & $\mathrm{NS}^{\mathrm{b}}$ & $0.81(0.53-1.24)$ & NS & $0.74(0.39-1.38)$ & NS & $1.05(0.66-1.7)$ & NS \\
\hline monosaccharides & $0.73(0.45-1.17)$ & NS & $0.88(0.57-1.34)$ & NS & $0.89(0.48-1.64)$ & NS & $1.09(0.67-1.78)$ & NS \\
\hline total fat & $1.75(0.84-3.6)$ & NS & $0.91(0.51-1.63)$ & NS & $2.97(1.01-9.96)$ & $\mathrm{SS}$ & $0.71(0.38-1.33)$ & NS \\
\hline cholesterol & $1.16(0.58-2.34)$ & NS & $0.61(0.34-1.12)$ & NS & $1.14(0.46-2.85)$ & NS & $0.84(0.43-1.65)$ & NS \\
\hline SFA & $2.40(1.02-6.39)$ & $\mathrm{SS}^{\mathrm{c}}$ & - & - & $1.76(0.52-6.01)$ & NS & $0.74(0.35-1.58)$ & NS \\
\hline PUFA & $0.81(0.48-1.38)$ & NS & $0.88(0.54-1.43)$ & NS & $1.01(0.48-2.09)$ & NS & $1.26(0.72-2.22)$ & NS \\
\hline dietary fibre & $1.54(0.88-2.7)$ & NS & $1.18(0.7-1.99)$ & NS & $1.25(0.60-2.60)$ & NS & $1.43(0.81-2.54)$ & NS \\
\hline vegetables and fruits & $1.11(0.68-1.78)$ & NS & $0.88(0.57-1.37)$ & NS & $1.14(0.61-2.13)$ & NS & $0.91(0.55-1.50)$ & NS \\
\hline overweight, obesity & $2.27(1.22-4.23)$ & $\mathrm{SS}$ & $2.35(1.28-4.34)$ & SS & $2.41(1.15-5.03)$ & SS & $1.48(0.77-2.80)$ & NS \\
\hline waist circumference & $2.03(1.26-3.24)$ & $\mathrm{SS}$ & $1.80(1.18-2.76)$ & SS & $2.19(1.19-4.04)$ & SS & $1.96(1.21-3.16)$ & SS \\
\hline smoking cigarettes & $1.38(0.84-2.27)$ & NS & $1.34(0.85-2.11)$ & NS & $1.18(0.62-2.26)$ & NS & $1.65(1.1-2.70)$ & SS \\
\hline physical activity & $0.53(0.30-0.94)$ & SS & $0.78(0.45-1.34)$ & NS & $1.88(1.06-3.36)$ & SS & $0.76(0.42-1.40)$ & NS \\
\hline
\end{tabular}

${ }^{a}$ - adjusted odds ratio $(95 \% \mathrm{Cl}),{ }^{b}-$ no statistical significance $(\mathrm{NS}),{ }^{\mathrm{c}}-$ statistical significance (SS), SFA - saturated fatty acid, PUFA - polyunsaturated fatty acid

The nutritional risk factors adopted in the study included: high energy value of diet, high contribution of energy derived from saccharose (monosaccharides), high intake of total fats, SFA and cholesterol as well as low contents of PUFA, dietary fibre, fruits and vegetables. Analyses showed that with a high intake of SFA the likelihood of a high concentration of cholesterol in blood of the examined group of boys increased over 2 times (age-adjusted odds ratio $[\mathrm{aOR}]=2.4 ; 95 \%$ confidence interval $[\mathrm{Cl}]$ [1.02-6.39]). They also demonstrated a statistically significant effect of excessive body mass, determined by the $\mathrm{BMI}$ value $(\mathrm{aOR}=2.27$ [1.22-4.23]), and high values of waist circumference $(\mathrm{aOR}=2.03$ [1.26-3.24]) on the increase in cholesterol concentration in blood plasma. The likelihood of a high concentration of triglycerides was shown to increase over 2 times at overweight and obesity $(\mathrm{aOR}=2.35[1.28-4.34])$, and especially at increased values of waist circumference $(\mathrm{aOR}=1.8$ [1.18-2.76]). This risk of a high concentration of LDL-cholesterol was observed to increase with an increasing intake of total fat $(\mathrm{aOR}=2.97$ [1.01-9.96]), high BMI values $(\mathrm{aOR}=2.41[1.15-5.03])$ and high values of waist circumference $(\mathrm{aOR}=2.19$ [1.19-4.04]), and at a low physical activity $(\mathrm{aOR}=1.88[1.06-3.36])$. In the group of the examined 16-18-year-old boys analyses showed about 2-fold increase in the risk of a low concentration of HDL-cholesterol at high values 
of waist circumference $(\mathrm{aOR}=1.96$ [1.21-3.16]). Of importance appeared to be also the habit of smoking cigarettes that reduced significantly the concentration of that cholesterol fraction $(\mathrm{aOR}=1.65$ [1.21-2.70]) in respect of its concentration recorded in the nonsmoking boys.

Results of the logistic regression analysis indicate that overweight and obesity, high values of waist circumference in particular, affected blood lipid parameters to the most significant effect. Analyses were also conducted for effects of lifestyle factors (diet, physical activity, smoking cigarettes) on the nutritional status of the boys (BMI, waist circumference).

Results of odds ratio analysis demonstrated that the likelihood of high BMI values was increasing 2.5 times at a low intake of dietary fibre $(\mathrm{aOR}=2.53$ [1.314.91]) (Table 3). (research in 2004 and 2014, respectively), which was similar to that in the reported study. Similar values of cholesterol concentration were shown in blood plasma of boys living in Germany $(156.0 \mathrm{mg} / \mathrm{dl})$ [37]. Identical average total serum cholesterol $(156 \pm 28 \mathrm{mg} /$ dl) was found in a study of children and adolescents (6-14 years) from primary and secondary schools in a community of 14 cities in the south of Italy [28]. A study by Murakami et al. [30] showed that mean cholesterol values in children $(\mathrm{n}=324)$ and adolescents $(\mathrm{n}=523)$ are $164.0 \mathrm{mg} / \mathrm{dl}$ and $155.5 \mathrm{mg} / \mathrm{dl}$, respectively. I $n$ the group of 1427 participants (715 boys and 712 girls) aged 6-20 years, the average total serum cholesterol concentration was $157.9 \mathrm{mg} / \mathrm{dl}$ [48].

Ample epidemiological surveys showed differences in lipid profile as affected by race, gender, ethnic group and sexual maturation [12, 15, 42]. In turn, the

Table 3. Effect of selected factors of lifestyle on an increase in the likelihood of overweight and obesity and a high value of waist circumference in the 16-18-year-old boys examined $(n=369)$

\begin{tabular}{|l|c|c|c|c|}
\hline \multicolumn{1}{|c|}{ Risk factors } & \multicolumn{2}{c|}{ BMI } & \multicolumn{2}{c|}{ Waist circumference } \\
\hline energy & $0.25(0.12-0.53)$ & SS $^{c}$ & $0.68(0.45-1.04)$ & NS \\
\hline monosaccharides & $0.58(0.32-1.05)$ & $\mathrm{NS}^{\mathrm{b}}$ & $0.79(0.52-1.22)$ & $\mathrm{NS}$ \\
\hline total fat & $0.57(0.27-1.19)$ & $\mathrm{NS}$ & $1.02(0.52-1.99)$ & $\mathrm{NS}$ \\
\hline cholesterol & $0.57(0.27-1.23)$ & $\mathrm{NS}$ & $1.24(0.66-2.30)$ & $\mathrm{NS}$ \\
\hline SFA & $0.76(0.30-1.94)$ & $\mathrm{NS}$ & $1.07(0.52-2.18)$ & $\mathrm{NS}$ \\
\hline PUFA & $0.82(0.41-1.61)$ & $\mathrm{NS}$ & $0.87(0.54-1.40)$ & $\mathrm{NS}$ \\
\hline dietary fibre & $2.53(1.31-4.91)$ & $\mathrm{SS}$ & $1.36(0.81-2.29)$ & $\mathrm{NS}$ \\
\hline vegetables and fruits & $0.45(0.22-0.95)$ & $\mathrm{SS}$ & $0.92(0.59-1.40)$ & $\mathrm{NS}$ \\
\hline smoking cigarettes & $1.72(0.93-3.19)$ & $\mathrm{NS}$ & $0.84(0.49-1.46)$ & $\mathrm{NS}$ \\
\hline physical activity & $0.62(0.30-1.26)$ & $\mathrm{NS}$ & $1.17(0.74-1.85)$ & $\mathrm{NS}$ \\
\hline
\end{tabular}

${ }^{a}$ - adjusted odds ratio $(95 \% \mathrm{Cl}),{ }^{b}-$ no statistical significance (NS), ${ }^{c}-$ statistical significance (SS), SFA - saturated fatty acid, PUFA - polyunsaturated fatty acid

\section{DISCUSSION}

The mean concentration of cholesterol in blood plasma of the boys examined in the study reached $156.8 \mathrm{mg} / \mathrm{dl}$. Yet, abnormalities, including threshold concentration and high concentration of cholesterol, were observed in a considerable percentage of the boys, i.e. in $18.4 \%$ and $8.1 \%$ of the group, respectively. The report by Nguyen et al. [32] shows that there is a high concentration of total cholesterol among American children and adolescents was $7.4 \%$. Adolescents aged 16-19 (8.9\%) had a higher incidence of high total cholesterol than children aged 6-8 (6.0\%) [32]. Analyses carried out on two subsamples consisting of the Beijing Child and Adolescent Metabolic Syndrome (BCAMS) in 2004 and the China Child and Adolescent Cardiovascular Health (CCACH) study in 2014 for children and adolescents aged 6-18 [9] showed that the mean concentration of cholesterol in their blood plasma reached 155 and $162 \mathrm{mg} / \mathrm{dl}$
National Health and Nutrition Examination Survey (NHANES) investigations conducted in the years 1999 to 2006 demonstrated that of $9.6 \%$ to $10.7 \%$ of the examined adolescents had a high concentration of total cholesterol ( $\geq 200 \mathrm{mg} / \mathrm{dl})$, whereas later surveys (NHANES 1999-2000) did not demonstrate any significant changes in this respect [12].

In the reported study, the mean concentration of LDL-cholesterol reached $86.8 \mathrm{mg} / \mathrm{dl}$, with its threshold concentration demonstrated in $8.7 \%$ and a high concentration in $4.6 \%$ of the boys examined. Amongst the American schoolchildren examined in the National Health and Nutrition Survey (NHANES) in 20112014, the mean concentration of LDL-cholesterol was similar to that recorded in Polish boys and reached $87 \mathrm{mg} / \mathrm{dl}$ [48]. Results of NHANES 1999 to 2006 investigations demonstrated that mean Concentrations of Low-Density Lipoprotein Cholesterol in US Adolescents accounted for $89.3 \mathrm{mg} / \mathrm{dl}$ (16-year-olds) and $88.9 \mathrm{mg} / \mathrm{dl}$ (17-year-olds), respectively. Based on 
statistical data collected in America, diversification of LDL-cholesterol concentration was demonstrated in a group of adolescents depending on their origin. Its mean concentration in 12-17-year-old boys of white race accounted for $89.7 \mathrm{mg} / \mathrm{dl}$, in the Mexicans - for $88.9 \mathrm{mg} / \mathrm{dl}$, and in the adolescents of black race - for $91.4 \mathrm{mg} / \mathrm{dl}$ [10]. Higher LDL cholesterol values were recorded among boys from 11-18 years of age in research Murakami et al. - $99.4 \mathrm{mg} / \mathrm{dl}$ [30].

In our study, the mean concentration of HDLcholesterol reached $52.4 \mathrm{mg} / \mathrm{dl}$, with the threshold concentration noted in $23.6 \%$ and a low concentration - in $1.6 \%$ of the boys examined. The value of the mean concentration was less favorable as compared to the Japanese 16-year-old adolescents $(59.6 \mathrm{mg} / \mathrm{dl})$, in which as many as $50 \%$ of the subjects displayed a low concentration of that cholesterol fraction [1]. Results of the NHANES 2011-2014, the Ito et al. and the Murakami et al. research investigations were alike $(53.5 \pm 12.4 \mathrm{mg} / \mathrm{dl} 59 \pm 11 \mathrm{mg} / \mathrm{dl}$ and $48.0 \mathrm{mg} / \mathrm{dl}$, respectively) [19, 30, 48].

The mean concentration of triglycerides in the boys surveyed in our study was at a level of $92.9 \mathrm{mg} / \mathrm{dl}$. A considerable percentage of the boys were displaying their threshold and high concentrations, i.e. $23.8 \%$ and $17.9 \%$ of the group, respectively. According to Abe et al. [1] the mean concentration of triglycerides in 16-yearold boys from Japan was $99.7 \mathrm{mg} / \mathrm{dl}$, and with a high level observed in nearly $25 \%$ of respondents from this age group. From cross-sectional studies based on data from the National Diet and Nutrition Survey (NDNS), the concentration of triglycerides among 11-19-yearold British boys was comparable with results reported in Poland - $90.34 \mathrm{mg} / \mathrm{dl}$ [30].

Disorders in the lipid profile occur with a greater frequency in adolescents with overweight and obesity $[29,41]$. Sarganas et al. found that about $34 \%$ of boys aged 11-17 years had low physical activity (up to 4 hours/ week) [37]. Research conducted by de Moraes et al. [8] and Sulo et al. [44] indicate a decrease in morbidity and mortality due to cardiovascular diseases. However, there are regions at the festival in which this rate continues to increase. It depends mainly on the proper control of health habits, such as reducing smoking, increasing and regularly exercising, and avoiding overweight and obesity. A study on children and adolescents from Florianopolis risk factors of cardiovascular diseases demonstrated that $3.5 \%$ of the study group were smoking cigarettes, spend about $2.6 \pm 2.3$ hours/day on inactive free time, and as much as $48 \%$ had a positive family interview in terms of circulatory system diseases [13]. The evaluation of the nutritive value of an average food ration in Murakami et al. research indicated a high contribution of energy derived from total fats $-34.6 \%$. It was shown that dietary fiber intake was not less than $26.6 \mathrm{~g} / 10 \mathrm{MJ}$ [28].
Our survey demonstrated even higher intake of total fats (36.4\% of energy), including those from SFA (14.4\% of energy), by the boys from Poland. Ca. $30 \%$ of the respondents were smoking cigarettes, and 17.3\% of the boys displayed a low physical activity. Worthy of notice is also the effect of dietary fibre content of food rations on the nutritional status of the boys examined. Results of the odds ratio demonstrated a 2.5 -fold increase in the likelihood of high BMI values at a low intake of dietary fibre (aOR=2.53 [1.31-4.91]).

Savva [38] was searching for relationships between biochemical and anthropometric factors of 10-14-yearold participants of the Research and Education Program for Child Health from Cyprus. In the boys examined, the mean concentration of cholesterol accounted for $170.8 \mathrm{mg} / \mathrm{dl}$, that of LDL-cholesterol for $95.3 \mathrm{mg} / \mathrm{dl}$, that of HDL-cholesterol - for $62.0 \mathrm{mg} /$ $\mathrm{dl}$, and that of triglycerides - for $67.7 \mathrm{mg} / \mathrm{dl}$. The BMI value reached $19.3 \mathrm{~kg} / \mathrm{m}^{2}$ and waist circumference $70.7 \mathrm{~cm}$ on average. Likewise in our study, at high BMI values, results of the odds ratio demonstrated a few fold increase in the risk of a high concentration of cholesterol (aOR=1.62 [1.20-2.17]), LDL-cholesterol $(\mathrm{aOR}=2.31$ [1.69-3.16]) and triglycerides $(\mathrm{aOR}=4.65$ [2.96-7.29]) in blood of the surveyed subjects. A high risk of health complications was also indicated at high values of waist circumference, adopted at a level of $\geq 75^{\text {th }}$ percentile: for a high concentration of total cholesterol $(\mathrm{aOR}=1.58$ [1.17-2.12]), LDL-cholesterol $(\mathrm{aOR}=2.11$ [1.54-2.89]), and triglycerides $(\mathrm{a} \mathrm{OR}=4.10$ [2.63-6.41]), at $\mathrm{p}<0.005$. In the reported own study, especially boys with overweight and obesity were characterized by an increased likelihood of a high concentration of total cholesterol $(\mathrm{aOR}=2.27$ [1.22$4.23])$, triglycerides $(\mathrm{aOR}=2.35$ [1.28-4.34]), and LDLcholesterol $(\mathrm{aOR}=2.41$ [1.15-5.03]). A high value of waist circumference, acc. to Katzmarzyk et al. [21], also posed a risk of a high concentration of cholesterol $(\mathrm{aOR}=2.03$ [1.26-3.24]), triglycerides $(\mathrm{aOR}=1.8[1.18$ 2.76]), and LDL-cholesterol $(\mathrm{aOR}=2.19$ [1.19-4.04]) as well as of a low concentration of HDL-cholesterol $(\mathrm{aOR}=1.96[1.21-3.16])$.

Investigations of Raitakari et al. [34] addressing risk factors of the circulatory system in children and adolescents from Finland confirmed that the impact of those factors at young age determined their health status in the adulthood.

Results of a research by Nemet et al. [31] demonstrated that a complex modification of a diet, eating habits and physical activity in obese children brought long-standing health benefits. Three-month intervention was found to yield noticeable effects in reduction of body mass (on average from 63.8 to 61.0 $\mathrm{kg}$ ), BMI value (from 28.5 to $26.8 \mathrm{~kg} / \mathrm{m}^{2}$ ). What is more, positive changes were observed in blood lipid profile, i.e.: concentration of total cholesterol (170.1 
- $147.8 \mathrm{mg} / \mathrm{dl})$, LDL-cholesterol (106.5-89.7 mg/dl), HDL-cholesterol (43.6-44.8 mg/dl) and triglycerides $(93.6-79.7 \mathrm{mg} / \mathrm{dl})$. Changes in lifestyle continued over a long time span were observed to result in the successive, beneficial reduction of body mass and lipid indices observed after a year since the intervention.

A proper body mass, insulin-susceptibility, blood lipid profile and arterial blood pressure in the childhood and adolescence minimize the risk of the incidence of a metabolic syndrome in the adulthood and are implicated in a fewer likelihood of the incidence of circulatory system diseases [25, 42].

\section{CONCLUSIONS}

Results obtained in the study enabled concluding that the lifestyle of young boys was determining the risk of their cardiovascular diseases. Overweight and obesity, visceral obesity in particular, were demonstrated to be significant risk factors of disorders in lipid metabolism of the boys surveyed in the study.

\section{Conflict of interest}

None declared.

\section{Acknowledgements}

None of the authors had any financial interest or support for this paper.

\section{Funding Sources}

This work was funded by the Research Committee in Poland under contract no. 09626.

\section{REFERENCES}

1. Abe Y., Okada T., Sugiura R., Yamauchi K., Murata M.: Reference Ranges for the Non-High-Density LipoproteinCholesterol Levels in Jap anese Children and Adolescents. J Atheroscler Thromb 2015; 22(7): 669-675 doi: 10.5551/jat.28100.

2. Baş M, Altan T., Dinçer D., Aran E., Kaya H.G., Yüksek $O$.: Determination of dietary habits as a risk factor of cardiovascular heart disease in Turkish adolescents. Eur J Nutr 2005; 44: 174-182 doi:10.1007/s00394-004-05098.

3. Boeing H., Bechthold A., Bub A., Ellinger S., Haller D., Kroke A., Leschik-Bonnet E., Müller M.J., Oberritter H., Schulze M., Stehle P., Watzl B.: Critical review: vegetables and fruit in the prevention of chronic diseases. Eur J Nutr 2012; 51: 637-663 doi:10.1007/ s00394-012-0380-y.

4. Bouziotas C., Koutedakis Y., Nevill A., Ageli E. Tsigilis N., Nikolaou A., Nakou A.: Greek adolescents, fitness, fatness, fat intake, activity, and coronary heart disease risk. Arch Dis Child 2004; 84: 41-44.

5. Cole T.J., Bellizzi M.C., Flegal K.M., Dietz W.H.: Establishing a standard definition for child overweight and obesity worldwide. BMJ 2000; 320: 1240-1243 doi: 10.1136/bmj.320.7244.1240.

6. Davis P.H., Dawson J.D., Riley W.A., Lauer R.M.: Carotid intimal-medial thickness is related to cardiovascular risk factors measured from childhood through middle age: The Muscatine Study. Circulation 2001; 104: 2815-2819 doi: 10.1161/hc4601.099486.

7. De Campos W., Stabelini Neto A., Bozza R., Zampier Ulbrich A/, Labronici Bertin R/, Gomes Mascarenhas L.P., Da Silva S.G., Eidi Sasaki J.: Actividad Física, Consumo de Lípidos y Factores de Riesgo para Aterosclerosis en Adolescentes. Arq Bras Cardiol 2010; 94(5): 583-589.

8. De Moraes S.A., Suzuki C.S., De Freitas I.C.M., Da Costa Júnior M.L.: Mortality Rates Due to Diseases of the Circulatory System (DCS) in Ribeirão Preto - SP, from 1980 to 2004. Arq Bras Cardiol 2009; 93(6): 589596.

9. Dong H., Yan Y., Liu J., Zhao X., Cheng H., Hou D., Huang G., Li S., Wang Y., Mi J.: Alarming trends in ideal cardiovascular health among children and adolescents in Beijing, China, 2004 to 2014. Int J Cardiol 2017; 231: 264-270 doi: 10.1016/j.ijcard.2016.12.027.

10. Farpour-Lambert N.J., Aggoun Y., Marchand L.M., Martin X.E., Herrmann F.R., Beghetti M.: Physical Activity Reduces Systemic Blood Pressure and Improves Early Markers of Atherosclerosis in PrePubertal Obese Children. JACC 2009; 54(25): 23962406 doi: 10.1016/j.jacc.2009.08.030.

11. Fontanive R.S., Costa R.S., Soares E.: Comparison between the nutritional status of eutrophic and overweight adolescents living in Brazil. Nutr Research 2002; 22,:667-678 doi: 10.1016/S0271-5317(02)00375-5.

12.Ford E.S., Li C., Zhao G., and Mokdad A.H.: Concentrations of Low-Density Lipoprotein Cholesterol and Total Cholesterol Among Children and Adolescents in the United States. Circulation 2009; 119: 1108-1115 doi: 10.1161/CIRCULATIONAHA.108.816769.

13. Giuliano I., Freitas S., Coutinho M., Zunino J., Caramelli B., Berenson G.: Distribution of HDLecholesterol and nonHDLecholesterol in Brazilian children and adolescents e The Floripa study. Nutr Metab Cardiovas 2011; 21: 33-38 doi: 10.1016/j.numecd.2009.08.002.

14. Gonzalez-Gallego J., Garcia-Mediavilla M.V., SanchezCampos S., Tunon M.J.: Fruit polyphenols, immunity and inflammation. Br J Nutr 2010; 104: 15-27 doi: 10.1017/S0007114510003910.

15. Hayman L.L., Meininger J.C., Daniels S.R., McCrindle B.W., Med R.J., Dennison B.A., Steinberger J., Williams C.L.: Primary Prevention of Cardiovascular Disease in Nursing Practice: Focus on Children and Youth (A Scientific Statement From the American Heart Association Committee on Atherosclerosis, Hypertension, and Obesity in Youth of the Council on Cardiovascular Disease in the Young, Council on Cardiovascular Nursing, Council on Epidemiology and Prevention, and Council on Nutrition, Physical Activity, and Metabolism). Circulatin 2007; 116: 344357 doi:10.1161/CIRCULATIONAHA.107.184595. 
16. Hooshmand F., Asghari G., Yuzbashian E., Mahdavi M., Mirmiran P., Azizi F.: Modified Healthy Eating Index and Incidence of Metabolic Syndrome In Children and Adolescents: Tehran Lipid and Glucose Study. J Pediatr 2018; 197: 134-139 doi: 10.1016/j.jpeds.2018.01.080.

17. Hu F.B., Stampfer M.J., Manson J.E., Rimm E., Colditz G.A., Speizer F.E., Hennekens C.H., Willett W.C.: Dietary fat intake and the risk of coronary heart disease in women. N. Engl J Med 1997; 337: 1491-1499 doi: 10.1056/NEJM199711203372102.

18. Hu F.B., Manson J.E., Willett C.: Type of dietary fat and risk of coronary heart disease: a critical review. J Am College Nutr 2001; 20: 5-19 doi: 10.1080/07315724.20 01.10719008 .

19. Ito S., Uenishi K., Ishida H., Uemura Y., Kodama M., Fukuoka H.: Relationships between Birth Weight and Serum Cholesterol Levels in Healthy Japanese Late Adolescents. J Nutr Sci Vitaminol 2014; 60: 108-113 doi: $10.3177 /$ jnsv.60.108.

20.Jarosz M.: Normy żywienia dla populacji polskiej. Wyd. IŻŻ, Warszawa, 2017.

21. Katzmarzyk P.T., Sathanur R.S., Chen W., Malina R.M., Bouchard C., Berenson G.S.: Body mass index, waist circumference, and clustering of cardiovascular disease risk factors in a biracial sample of children and adolescents. Pediatrics 2004; 114: 198-205 doi: 10.1542/ peds.114.2.e198.

22.Kouki R., Schwab U., Hassinen M., Komulainen P., Heikkila H., Lakka T.A., Rauramaa R.: Food consumption, nutrient intake and the risk of having metabolic syndrome: the DR's EXTRA Study. Eur $J$ Clin Nutr 2011; 65: 368-377.

23.Li H., Liao W., Yu H., Liu M., Yuan S., Tang B., Yang X., Song Y., Huang Y., Cheng S., Chen Z., Towne S.D., Mao Z., He Q.: Combined effects of fruit and vegetables intake and physical activity on the risk of metabolic syndrome among Chinese adults. PLoS ONE 2017; 12(11): 1-9 doi:10.1371/journal.pone.0188533.

24.Lim H., Xue H., Wang Y.: Association between obesity and metabolic co-morbidities among children and adolescents in South Korea based on national data. Public Health 2014; 14: 279, 1-9 doi: 10.1186/1471-245814-279.

25.Lim S., Jang H.Ch., Park K.S., Cho S., Lee M.G., Joung H., Mozumdar A., Liguori G.: Changes in Metabolic Syndrome in American and Korean Youth, 1997-2008. Pediatrics 2013, 131: 214-222 doi:10.1542/peds.20120761.

26.Lutsey P.L., Steffen L.M., Stevens J.: Dietary Intake and the Development of the Metabolic Syndrome. The Atherosclerosis Risk in Communities Study. Circulation 2008; 117: 754-76 doi: 10.1161/ CIRCULATIONAHA.107.716159.

27. Magkos F., Manios Y., Christakis G., Kafatos A.G.: Secular trends in cardiovascular risk factors among school-aged boys from Crete, Greece, 1982-2002. Eur J Clin Nutr 2005; 59: 1-7.

28. Martino F., Puddu P.E., Pannarale G., Colantoni C., Zanoni C., Martino E., Barillà F.: Arterial blood pressure and serum lipids in a population of children and adolescents from Southern Italy: The Calabrian Sierras Community Study (CSCS). Int J Cardiol, 2012; 168: 1108-1114 doi: 10.1016/j.ijcard.2012.11.045.

29. McCrindle B.W.: Cardiovascular consequences of childhood obesity. Can J Cardiol 2015; 31(2): 124-130 doi: 10.1016/j.cjca.2014.08.017.

30.Murakami K., Livingstone M.B.E.: Associations of eating frequency with adiposity measures, blood lipid profiles and blood pressure in British children and adolescents. Br J Nutr 2014; 111: 2176-2183 doi: 10.1017/ S0007114514000452.

31. Nemet D., Barkan S., Epstein Y., Friedland O., Kowen G., Eliakim A.: Short-and long-term beneficial effects of a combined dietary-behavioral-physical activity intervention for the treatment of childhood obesity. Pediatrics 2005; 115: 443-449 doi: 10.1542/peds.20042172.

32. Nguyen D., Kit B., Carroll M.: Abnormal Cholesterol Among Children and Adolescents in the United States 2011-2014. NCHS Data Brief 2015; 228: 1-8.

33. Przygodna B., Kunachowicz H., Nadolna I., Iwanow K.: Wartość odżywcza wybranych produktów spożywczych i typowych potraw. PZWL Wydawnictwo Lekarskie. Warszawa, 2019.

34.Raitakari O.T., Juonala M., Kähönen M., Taittonen L., Laitinen T., Mäki-Torkko N., Järvisalo M., Uhari M., Jokinen E, Rönnemaa T., Åkerblom H.K., Viikari J.S.A.: Cardiovascular risk factors in childhood and carotid artery intima-media thickness in adulthood. The Cardiovascular Risk in Young Finns Study. JAMA 2003; 290: 2277-2283 doi: 10.1001/jama.290.17.2277.

35. Report of the Expert Panel on Blood Cholesterol Levels in Children and Adolescents. National Cholesterol Education Program. Pediatrics 1992; 89(3): 525-577.

36.Rosário R., Santos R., Lopes L., Agostinis-Sobrinho C., Moreira C., Mota J., Póvoas S., Oliveira A., Padrão P., Moreira P., Abreu S.: Fruit, vegetable consumption and blood pressure in health adolescents: A longitudinal analysis from the LabMed study. Nutr Metab Cardiovas 2018; 28(10): 1075-1080 doi: 10.1016/j. numecd.2018.05.014.

37. Sarganas G., Schaffrath Rosario A., Neuhauser H.K.: Resting Heart Rate Percentiles and Associated Factors in Children and Adolescents. J Pediatr 2017; 187: 174181 doi: $10.1016 /$ j.jpeds.2017.05.021.

38.Savva S.C., Tornaritis M., Savva M.E., Kourides Y., Panagi A., Silikiotou N., Geargiou C. Kafatos A.: Waist circumference and waist-to-height ratio are better predictors of cardiovascular disease risk factors in children than body mass index. Int J Obes 2000, 24(11): 1453-1458 doi: 10.1038/sj.ijo.0801401.

39. Schaefer E.J.: Lipoproteins, nutrition, and heart disease. Am J Clin Nutr 2002, 75(2) 192-212 doi: 10.1093/ ajen/75.2.191.

40.Shin J.Y., Kim J.Y., Kang H.T., Han K.H., Shim J.Y.: Effect of fruits and vegetables on metabolic syndrome: a systematic review and meta-analysis of randomized controlled trials. Int J Food Sci Nutr 2015; 66(4): 416425 doi: 10.3109/09637486.2015.1025716. 
41. Skinner A.C., Perrin E.M., Moss L.A., Skelton J.A.: Cardiometabolic risks and severity of obesity in children and young adults N Engl J Med 2015; 373(14): 1307-1317 doi: 10.1056/NEJMoa1502821.

42.Slhessarenko N., Jacob C.M.A., Azevedo R.S., Fontes C.J.F., Novak G.V., Andriolo A.: Serum lipids in Brazilian children and adolescents:determining their reference intervals. BMC Public Health 2015; 15: 1-8 doi: 10.1186/s12889-015-1359-4.

43. Suárez-Ortegon M.F., Ramirez-Vélez R., Mosquera M., Méndez F., Aguilar-de Plata C.: Prevalence of Metabolic Syndrome in Urban Colombian adolescences aged 1016 years using three different pediatric definitions. J of Trop Pediatr 2013; 59: 145-149 doi: 10.1093/tropej/ fms054.

44.Sulo G., Igland J., Vollsets S.E., Nygård O., Øyen N., Tell G.S.: Cardiovascular disease and diabetes mellitus in Norway during 1994-2009 CVDNOR - a nationwide research Project. Norsk Epidemiologi 2013; 23 (1): 101107 doi: 10.5324/nje.v23i1.1609.

45. Syme C., Czajkowski S., Shin J., Abrahamowicz M., Leonard G., Perron M., Richer L., Veillette S., Gaudet D., Strug L., Wang Y., Xu H., Taylor G., Paus T., Bennett
S., Pausova Z.: Glycerophosphocholine Metabolites and Cardiovascular Disease Risk Factors in Adolescents. Circulation 2016; 134(21): 1629-1636 doi: 10.1161/ CIRCULATIONAHA.116.022993.

46.Te Morenga L., Montez J.M.: Health effects of saturated and trans-fatty acid intake in children and adolescents: Systematic review and meta-analysis, PLoS ONE 2017; 12(11): 1-20 doi: 10.1371/journal.pone.0186672.

47. WHO: Diet, Nutrition and the prevention of chronic diseases, Report of a joint WHO/FAO Expert Consultation, Technical Report Series 916, 2003, Geneva. http://whqlibdoc.who.int/trs/WHO_TRS_916. pdf

48.Zang X., Huang H., Zhuang Z., Chen R., Xie Z., Xu $C$., $M o$ X: The association between serum copper concentrations and cardiovascular disease risk factors in children and adolescents in NHANES. Environ Sci Pollut Res 2018; 25(17): 16951-16958 doi: 10.1007/ s11356-018-1816-6.

Received: 12.07 .2020

Accepted: 30.09 .2020 